\title{
Biot's breathing associated with acute bacterial meningitis in a child
}

\author{
Alex Guri, ${ }^{1}$ Eric Scheier, ${ }^{1}$ Meital Adi, ${ }^{2}$ Mikhael Chigrinsky ${ }^{3}$
}

'Paediatrics, Kaplan Medical Center, Rehovot, Israel ${ }^{2}$ Radiology, Kaplan Medical Center, Rehovot, Israel

${ }^{3}$ Paediatric Intensive Care Unit, Kaplan Medical Center, Rehovot, Israel

\section{Correspondence to}

Dr Alex Guri,

alexgur@clalit.org.il

Accepted 16 June 2018
Check for updates

To cite: Guri A, Scheier $E_{\text {, }}$ Adi M, et al. BMJ Case Rep Published Online First: [please include Day Month Year]. doi:10.1136/bcr-2018225774

\section{DESCRIPTION}

A 19-month-old boy presented to the emergency room of our hospital with fever and drowsiness following asymmetric focal seizure. On examination the patient was somnolent, had signs of meningeal irritation and intermittent nystagmus. Laboratory examination revealed increased C-reactive protein $(200 \mathrm{mg} / \mathrm{L})$, procalcitonin $(25.9 \mathrm{ng} / \mathrm{mL})$ and hyponatraemia $(132 \mathrm{mEq} / \mathrm{L})$. The initial CT of the brain was normal. Given presumed meningoencephalitis, intravenous dexamethasone, vancomycin, ceftriaxone and acyclovir treatment was started, and the child was admitted to the paediatric intensive care unit. Several hours after the admission, irregular, jerky respirations appeared, consistent with Biot's breathing (figure 1). The patient developed hypertension $(129 / 90 \mathrm{~mm} \mathrm{Hg})$ and relative bradycardia $(90 \mathrm{bpm})$. Due to these signs, consistent with increased intracranial pressure, lumbar puncture was deferred and the child received mannitol with notable improvement in his condition. On hospital day 2, lumbar puncture revealed turbid fluid with an opening pressure of $5 \mathrm{cmH}_{2} \mathrm{O}$, white blood cells $340 / \mu \mathrm{L}$ and red blood cells $1700 / \mu \mathrm{L}$. BioFire FilmArray Meningitis/Encephalitis panel detected Streptococcus pneumoniae DNA, and the blood culture grew S. pneumoniae. On day 3 of hospitalisation, left hemiparesis and feeding difficulties developed with recurrence of focal seizures controlled by midazolam and phenytoin. His condition improved gradually and he was transferred to the paediatric ward on hospital day 5 . Brain MRI revealed multiple foci in temporal lobe white matter and numerous bilateral cortical and subcortical microbleeds, compatible with vasculitis (figure 1). The child continued a 4-week course of ceftriaxone and anticonvulsive therapy (carbamazepine and levetiracetam). The auditory brainstem response examination showed severe bilateral hearing loss. Five weeks after the initial admission the patient was transferred to the paediatric rehabilitation facility, and he subsequently received a cochlear implant. After extensive rehabilitation, the patient had almost complete resolution of all deficits except hearing.

Camille Biot made his observations on breathing patterns in 1875 while describing a patient with tuberculous meningitis. ${ }^{1} \mathrm{He}$ distinguished this pattern from previously described Cheyne-Stokes breathing and named it 'meningitic rhythm'. In

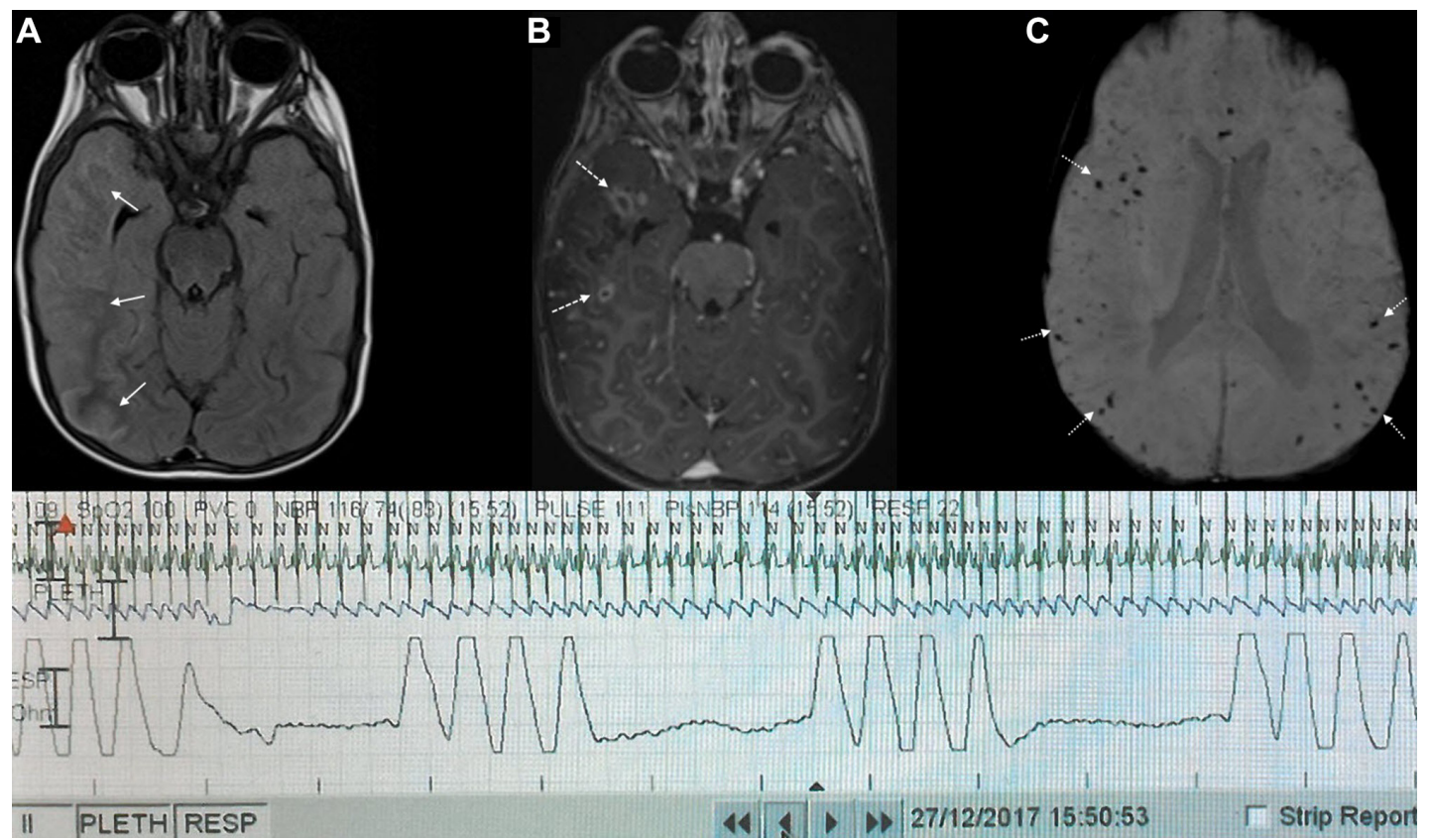

Figure 1 Top images: Axial T2-fluid-attenuated inversion recovery (FLAIR) (A), contrast enhanced T1 (B) and susceptibility-weighted imaging (SWI) (C) MRI scans showing cortical and subcortical hyperintensity in the right temporal lobe (black arrows in A) with multiple foci of patchy ring-like enhancement in temporal lobe white matter (dotted arrows in B) and numerous bilateral cortical and subcortical microbleeds (white arrows in C), compatible with vasculitis. Bottom image: 'Biot's breathing' on paediatric intensive care unit (PICU) monitor. 
contrast to Cheyne-Stokes breathing, the respirations of Biot's breathing pattern lack the crescendo-decrescendo 'diamondshaped' cycles. The original publication by Biot described irregular respirations with alternating depth and without any constant pattern, but over the years semantic confusion developed, and the terms 'Biot's breathing', 'cluster breathing' and 'ataxic breathing' were erroneously used interchangeably. ${ }^{2}$ The appropriate current term for the pattern originally described by Biot is 'ataxic breathing', which is associated with a medullary lesion and may be a warning sign of brainstem compression. In our case, 'Short-cycle periodic breathing' is a more accurate term. ${ }^{3}$ This breathing pattern is seen with increased intracranial pressure, opioid intoxication, lower pontine lesions or expanding lesions

\section{Learning points}

'Biot's breathing' is a term rarely used today that describes an abnormal respiration pattern. Biot's breathing occurs when periods of apnoea alternate irregularly with series of breaths of equal depth that terminate abruptly, and is associated with meningitis.

- The use of historical eponyms is widespread, but descriptive terms often are more precise.

- Any deviation from normal breath pattern associated with central nervous system damage is a foreboding clinical sign. in the posterior fossa. ${ }^{3}$ Although the term 'Biot's breathing' can be found in textbooks on physical examination and physiology, and even on Wikipedia, there are only rare mentions of Biot's breathing in clinical literature, most frequently in the context of meningitis.

Acknowledgements The authors thank Dr Eli Shapiro, the head of paediatric intensive care unit in our hospital, for his supervision and asistance in editing the manuscript.

Contributors AG, ES, MA, MC: discussion and analysis of the case and the image choice. AG: drafting the manuscript. MA: radiologic image analysis and marking. ES, $M C, M A$ : revising the manuscript critically for important remarks. AG, ES, MA: final approval of the manuscript.

Funding The authors have not declared a specific grant for this research from any funding agency in the public, commercial or not-for-profit sectors.

Competing interests None declared.

Patient consent Parental/guardian consent obtained.

Provenance and peer review Not commissioned; externally peer reviewed.

(C) BMJ Publishing Group Ltd (unless otherwise stated in the text of the article) 2018. All rights reserved. No commercial use is permitted unless otherwise expressly granted.

\section{REFERENCES}

1 Wijdicks EF. Biot's breathing. J Neurol Neurosurg Psychiatry 2007;78:512-3.

2 MENINGITIC breathing. J Am Med Assoc 1957;165:1568.

3 Berger JR. Stupor and Coma. In: Daroff R, Jankovic JMD, Mazziotta J, Pomeroy S, et al. eds. Bradley's neurology in clinical practice, 2016:34-50.

Copyright 2018 BMJ Publishing Group. All rights reserved. For permission to reuse any of this content visit http://group.bmj.com/group/rights-licensing/permissions.

BMJ Case Report Fellows may re-use this article for personal use and teaching without any further permission.

Become a Fellow of BMJ Case Reports today and you can:

- Submit as many cases as you like

- Enjoy fast sympathetic peer review and rapid publication of accepted articles

- Access all the published articles

- Re-use any of the published material for personal use and teaching without further permission

For information on Institutional Fellowships contact consortiasales@bmjgroup.com

Visit casereports.bmj.com for more articles like this and to become a Fellow 